Linnæus on the subject, carried out a series of observations and finally convinced himself that the spores of fungi, like seeds of flowering plants, were unrelated to the animalculæ which appeared when they were placed in water. But others, incuding Sir John Hill, persisted with Munckhausen's theory.

Necker, in 1783, published a treatise expounding the view that fungi were like plants in their method of nutrition, development and growth, but that they differed in origin. He therefore regarded them as a new kingdom between minerals and animals and proposed for it the name Regnum mesymale-the intermediate kingdom. Villement also proposed a new class for them, namely, pseudo-zoo-lithophytes.

Discussion on the origin of fungi which had been rife ended in 1783, and the conception of spontaneous generation was finally exploded by Pasteur, whose forerunners in this field of thought were Redi and Spallanzani.

In 1784, Hedwig published his classic work on cryptogams, in which he proposed the use of the name 'spore' for the reproductive structures of these plants. In 1837, Léveillé announced that spores are essentially different from seeds since they do not contain embryos. Hedwig's work was incorporated in the general mycological structure by Persoon, to whom was due perhaps more than to anyone else the foundation of systematic mycology. During 1815-74, the recognized authority on the classification of the fungi was Elias Fries.

The highly complex pleomorphy of the rust fungi took a long time to unravel, although heterœcism was much to the fore because of the damage caused by the rust of wheat. Heterœeism was proved conclusively in wheat by de Bary in 1865, while Oersted, in the same year, independently proved heterœcism in Gymnosporangium on junipers and pears.

The important part played by fungi in causing diseases of plants was obvious so soon as it was realized that mildews, etc., were fungi.

\title{
Training of Teachers
}

A DETERMINATION that teachers, as a body, should not be inferior to other professions in respect of their education and training led the National Union of Teachers to undertake two years ago an investigation of the whole question of the training of teachers and the grants available for the purpose. The investigating committee, composed of six members of the Union's executive and six representatives of university training departments, of training colleges and of secondary schools, completed its work last February, and the report* has been published in the form of a book of 360 pages including a summary of the principal conclusions formulated in 95 articles. These range over a wide field, including recruitment and placing as well as training. Although a number of the recommendations concern the content of training courses, the committee regarded such things as internal matters for the training institutions. In a preliminary chapter a strong case is made out for requiring some actual experience of teaching practice before admission to a training institution, this being desirable less for its intrinsic value than as a test of aptitude for the career of a teacher, for it is notorious that many recipients of grants for training have no such aptitude nor even any serious desire to take up teaching as a profession. It is proposed to make an officer of the local education authority report on the teaching potentialities, personality and general suitability for the teaching profession of every applicant for a place in a university training department or training college.

The vital importance of teaching practice as part of the college or university course is also emphasized and it is mainly to provide adequate opportunities for this that the report recommends the lengthening of the course to three years as a minimum. The report is equally emphatic as to the influence of residential conditions during the years of training, and proposes that residence in a college or hostel should be compulsory for all and that funds should be provided for ensuring that hostels are run on the

* The Training of Teachers and Grants to Intending Teachers. Being a Report of a Committee of Investigation appointed by the Executive of the National Union of Teachers and adopted by the Executive on 3rd March 1939. Pp. xxxi+328. (London: National Union of Teachers, 1939.) right lines as recommended by the University Grants Committee in its last quinquennial review.

Above all, the committee was concerned to press on towards the ideal of "a unified profession to serve a unified system of education", implying for the teacher trained in a training college a status equivalent to that of the university graduate. To this end it is proposed to develop the connexion between training colleges and universities so that the former may eventually become integral parts of the latter. On the crucial question of the staffing of training colleges the report observes that salaries are inadequate and prospects of promotion relatively small but leaves it at that, the additional grants it proposes for training colleges being intended to enable them to reduce the fees payable by students, not to make possible a higher standard of qualification and status for the staffs. It quotes with approval a suggestion that the staffs might be strengthened by the addition of two or three experienced practising teachers seconded for a definite period of years.

The report concludes with a paragraph on the need for immediate investigation by the Board of Education. Should such an investigation be made, it is to be hoped that the fundamental importance in this connexion of the progress of science will be recognized. The progress of science and its application has brought about changes which should affect the training of teachers both in respect of science teaching and as calling for a change in the attitude of all teachers towards science. Progress is so rapid that science teaching in schools is bound to lag hopelessly behind and be correspondingly ineffective unless it is kept constantly under review by competent observers, and modified and readjusted whenever necessary, and unless examining bodies are compelled to take cognizance of such changes. On the other hand, the social and economic transformations resulting from it are so sweeping that it is of the first importance that science should form an integral part of the curriculum of the primary as well as the post-primary school and that all teachers should grasp the relations of science teaching to the teaching of other subjects. The question is discussed in Prof. Bernal's recent book on "The Social Function of Science". 